\title{
ОСОБЛИВОСТІ МОРФОЛОГІЧНИХ ЗМІН СІТКІВКИ У ХВОРИХ НА ДІАБЕТИЧНУ ПОЛІНЕЙРОПАТІЮ ЗАЛЕЖНО ВІД ТЯЖКОСТІ ЗАХВОРЮВАННЯ
}

\begin{abstract}
У роботі описано зміни товщини сітківки у фовеолі, верхній та нижній половинах сітківки, а також у темпоральному, верхньому, назальному та нижньому квадрантах пара- та перимакулярної зон у хворих на діабетичну полінейропатію залежно від тяжкості захворювання та у порівнянні до показників здорових осіб.

Ключові слова: иукровий діабет, діабетична полінейропатія, морфологічні зміни сітківки, оптична когерентна томографія.
\end{abstract}

Відомо, що діабетична полінейропатія (ДПН) $є$ чинником ризику порушення структурної цілісності сітківки у хворих на цукровий діабет (ЦД) незалежно від наявності діабетичної ретинопатії (ДР) [11-13]. Клінічно за допомогою оптичної когерентної томографії (ОКТ) у хворих на ЦД було виявлено раннє потоншання шару нервових волокон, гангліонарного шару та інших шарів сітківки, що відбувалось ще до появи ознак ДР $[2,7,9,16]$. Тобто, нейропатія може бути наявною і без клінічних ознак ДР, а їхня відсутність не виключає існування ретинальних або нейроретинальних ускладнень ЦД [15]. Хворі на ЦД можуть мати недіагностовану периферичну ДПН та поєднані $з$ нею нейроретинальні ускладнення [15]. Деякі дослідники вказують на те, що низка змін сітківки, зорового нерва та зорових функцій може корелювати з ДПН, а тому їх оцінка може дати додаткову інформацію про виявлення та визначення ступеня іï тяжкості $[6,10,11,13,14]$.

Мета роботи: вивчення морфологічних змін сітківки у хворих на діабетичну полінейропатію залежно від тяжкості захворювання за допомогою оптичної когерентної томографії.

Матеріали та методи. Аналіз морфологічних змін сітківки здійснювався на основі даних обстеження 575 хворих (1150 очей) на ЦД 2-го типу. Була відібрана група хворих на ЦД 2-го типу з відсутньою глаукомою в анамнезі, у яких показники тонометричного тиску не перевищували 21 мм рт. ст. за Гольдманом. У дослідження включали очі з еметропією або з гіперметропією чи міопією слабкого ступеня; без катаракти або з початковою віковою катарактою; без хірургічних втручань в анамнезі, в тому числі лазерних. Вік хворих коливався від 44 до 69 років, у середньому складав $55,9 \pm 7,8$ року. Тривалість ЦД до 5 років помічалася у більшості хворих $(71,8 \%, 413$ осіб), від 5 до 10 років - у 16,2\% хворих (93 особи), вище 10 років - у 12,0\% хворих (69 осіб). ДР було виявлено на $18,5 \%$ очей хворих на ЦД (213 очей): непроліферативна форма - на $11,7 \%$ очей (135 очей), препроліферативна - на $3,7 \%$ очей (43 ока), проліферативна - на $3,1 \%$ очей ( 35 очей).

Згідно класифікації ДПН з урахуванням тяжкості [1], у 63,5\% хворих (365 осіб) на ЦД діагноз ДПН був виключений (N0 стадія). ДПН було діагностовано у $36,5 \%$ хворих на ЦД (210 осіб). Асимптоматична ДПН помічалась у 17,5\% хворих на ЦД (101 особа): N1A стадія - у 8,1\% хворих (47 осіб), N1B стадія у 9,4\% хворих (54 особи); симптоматична ДПН - у 15,5\% хворих на ЦД (89 осіб): N2A стадія - у 8,0\% хворих (46 осіб), N2B стадія - у 7,5\% хворих (43 особи); стадія тяжких ускладнень (N3 стадія) - у 3,5\% хворих на ЦД (20 осіб). Контрольну групу склали 50 здорових осіб (100 очей).

Крім стандартних (візометрії, тонометрії, офтальмоскопії), методи офтальмологічного дослідження включали ОКТ сітківки та зорового нерва. Для спектральної ОКТ використовували RTVue-100 (Optovue, США) 3 роздільною здатністю 5 мікрон. Аналіз загальної товщини сітківки проводили в макулярній зоні на квадратній площі $5 \times 5$ мм. Вимірювали товщину сітківки у фовеолі, пара- і перимакулярно, 3 діаметром дослідження 1 мм, 3 мм та 5 мм відповідно. Визначали товщину у верхній та нижній половинах сітківки, а також у темпоральному, верхньому, назальному та нижньому квадрантах пара- та перимакулярної зон.

Статистична обробка матеріалу здійснювалась із використанням методів варіаційної статистики за допомогою програмного комп'ютерного забезпечення Microsoft Excel 2000. Розраховували середню арифметичну величину (М), стандартне відхилення $(\sigma)$, стандартну похибку середнього (m), коефіцієнт варіації (Cv), показник достовірності відмінності (p), 
95\% інтервал довіри (ІД). У роботі прийнятий критерій значимої відмінності $\mathrm{p}<0,05$.

Результати та їх обговорення. Аналізуючи показник фовеолярної товщини сітківки у хворих на ДПН, виявили ії залежність від тяжкості захворювання (табл. 1). Середній показник фовеолярної товщини сітківки у хворих на асимптоматичну А ДПН був на $9,1 \%$, асимптоматичну В ДПН - на $8,9 \%$, стадію тяжких ускладнень ДПН - на 12,7\% менше відповідного у контрольній групі $(263,9 \pm 25,9$ мкм) $(\mathrm{p}<0,05)$. У хворих на ЦД без ДПН, при симптоматичній А й В ДПН, даний показник достовірно не відрізнявся від такого в групі контролю (p>0,05). Найнижчий середній показник фовеолярної товщини сітківки відзначили у хворих на стадію тяжких ускладнень ДПН. При симптоматичній А ДПН даний показник на $17,0 \%$, при симптоматичній В ДПН - на $14,1 \%$ ( $<<0,001)$, у хворих на ЦД без ДПН - на 11,0\% (p<0,05) перевищував відповідний при стадії тяжких ускладнень ДПН.

Як видно з табл. 1 середній показник середньої товщини парамакулярної зони сітківки у хворих на ЦД без ДПН при асимптоматичній А й В ДПН, симптоматичній А й В ДПН та стадії тяжких ускладнень ДПН даний показник достовірно не відрізнявся від такого у групі контролю $(321,3 \pm 13,0$ мкм) $(\mathrm{p}>0,05)$.

Аналізуючи показники товщини парамакулярної зони темпорального, назального, верхнього та ниж- нього секторів сітківки у хворих на ДПН, не виявили іiі залежності від тяжкості захворювання (табл. 2).

Аналізуючи показник середньої товщини перимакулярної зони сітківки у хворих на ДПН, також не виявили iї залежності від тяжкості захворювання. Так, вищезазначений показник у хворих на ЦД без ДПН коливався

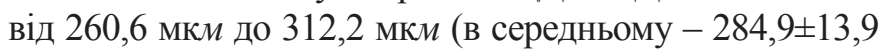
мкм), а 95\%-й інтервал довіри - 280,0-289,8 мкм (див. рис.). При асимптоматичній А ДПН даний показник коливався від 247,7 мкм до 318,7 мкм (в середньому $281,2 \pm 17,5$ мкм) з 95\%-м інтервалом довіри 274,8-287,6 мкм. У хворих на асимптоматичну В ДПН коливався від 245,7 мкм до 328,7 мкм (в середньому $-280,3 \pm 18,3$ мкм), а 95\%-й інтервал довіри становив 272,2-288,4 мки. При симптоматичній А ДПН даний показник коливався від 261,7 мкм до 353,8 мкм (в середньому - 291,1 29,3 мкм) з 95\%-м інтервалом довіри 275,8-306,4 мкм.

У хворих на симптоматичну В ДПН показник середньої товщини перимакулярної зони сітківки коливався від 253,1 мки до 376,6 мкм (в середньому - 290,6 30,3 мкм), а 95\%-й інтервал довіри становив 275,0-305,9 мкм. При стадії тяжких ускладнень ДПН даний показник коливався від 216,0 мки до 332,9 мкм (в середньому - 278,2士30,7 мкм) з 95\%-м інтервалом довіри 262,1304,3 мкм. Таким чином, середній показник середньої товщини перимакулярної зони сітківки у хворих на ЦД без ДПН, при асимптоматичній А й В ДПН, симптома-

\section{Показники фовеолярної та середньої товщини парамакулярної зони сітківки} у хворих на ДПН залежно від тяжкості захворювання

\begin{tabular}{|c|c|c|c|}
\hline Досліджувані групи & Показники & Фовеолярна, мкм & Середня, мкм \\
\hline \multirow{3}{*}{$\begin{array}{c}\text { контроль, } \\
\mathrm{n}=100 \text { очей }\end{array}$} & $\mathrm{M} \pm \mathrm{m}$ & $263,9 \pm 25,9^{\prime}$ & $321,3 \pm 13,0$ \\
\hline & коливання & $228,8-302,6$ & $299,3-346,0$ \\
\hline & 95\%-й ІД & $256,6-270,4$ & $317,5-326,0$ \\
\hline \multirow{3}{*}{$\begin{array}{l}\text { N0 стадія, } \\
\text { n=730 очей }\end{array}$} & $\mathrm{M} \pm \mathrm{m}$ & $255,9 \pm 25,3^{\prime}$ & $319,6 \pm 13,7$ \\
\hline & коливання & $204,3-321,4$ & $295,7-347,8$ \\
\hline & 95\%-й ІД & $248,3-262,2$ & $214,2-224,3$ \\
\hline \multirow{3}{*}{$\begin{array}{c}\text { N1А стадія, } \\
\text { n=94 ока }\end{array}$} & $\mathrm{M} \pm \mathrm{m}$ & $239,8 \pm 25,5^{*}$ & $316,6 \pm 15,5$ \\
\hline & коливання & $192,4-290,6$ & $284,3-345,3$ \\
\hline & 95\%-й ІД & $227,5-250,8$ & $211,3-221,2$ \\
\hline \multirow{3}{*}{$\begin{array}{l}\text { N1B стадія, } \\
\text { n=108 очей }\end{array}$} & $\mathrm{M} \pm \mathrm{m}$ & $240,4 \pm 27,9^{*}$ & $320,5 \pm 25,6$ \\
\hline & коливання & $187,7-301,9$ & $283,4-376,3$ \\
\hline & 95\%-й ІД & $225,1-249,8$ & $305,3-334,9$ \\
\hline \multirow{3}{*}{$\begin{array}{c}\text { N2A стадія, } \\
\text { n=92 ока }\end{array}$} & $\mathrm{M} \pm \mathrm{m}$ & $269,6 \pm 38,3^{\prime}$ & $327,0 \pm 30,4$ \\
\hline & коливання & $234,7-362,6$ & $271,9-369,3$ \\
\hline & 95\%-й ІД & $250,4-291,5$ & $218,2-245,9$ \\
\hline \multirow{3}{*}{$\begin{array}{l}\text { N2B стадія, } \\
\text { n=86 очей }\end{array}$} & $\mathrm{M} \pm \mathrm{m}$ & $262,9 \pm 40,1^{\prime}$ & $326,2 \pm 31,2$ \\
\hline & коливання & $219,5-386,2$ & $269,3-348,8$ \\
\hline & 95\%-й ІД & $250,4-291,5$ & $205,7-243,7$ \\
\hline \multirow{3}{*}{$\begin{array}{l}\text { N3 стадія, } \\
\text { n=40 очей }\end{array}$} & $\mathrm{M} \pm \mathrm{m}$ & $230,5 \pm 41,6^{*}$ & $314,8 \pm 32,4$ \\
\hline & коливання & $182,6-358,7$ & $251,7-401,1$ \\
\hline & 95\%-й ІД & $209,7-250,4$ & $299,7-330,3$ \\
\hline
\end{tabular}

Примітки:

* - достовірна відмінність між середнім значенням показника в досліджуваній та контрольній групах;

' - достовірна відмінність між середнім значенням показника у досліджуваній групі та групі хворих на N3 стадію ДПН 
Показники товщини різних секторів парамакулярної зони сітківки у хворих на ДПН

Таблиия 2 залежно від тяжкості захворювання

\begin{tabular}{|c|c|c|c|c|c|}
\hline Групи & Показники, мкм & Темпоральна & Верхня & Назальна & Нижня \\
\hline \multirow{3}{*}{$\begin{array}{c}\text { контроль, } \mathrm{n}=100 \\
\text { очей }\end{array}$} & $\mathrm{M} \pm \mathrm{m}$ & $313,4 \pm 12,3$ & $324,7 \pm 14,8$ & $326,8 \pm 13,3$ & $320,4 \pm 11,7$ \\
\hline & коливання & $301,3-338,4$ & $293,8-350,7$ & $296,8-348,7$ & $303,7-346,9$ \\
\hline & $95 \%$-й ІД & $309,6-316,9$ & $320,1-329,0$ & $321,7-331,3$ & $317,1-324,5$ \\
\hline \multirow{3}{*}{$\begin{array}{c}\text { N0 стадія, } \mathrm{n}=730 \\
\text { очей }\end{array}$} & $\mathrm{M} \pm \mathrm{m}$ & $311,0 \pm 13,2$ & $322,0 \pm 15,1$ & $325,5 \pm 14,8$ & $319,9 \pm 11,8$ \\
\hline & коливання & $291,5-340,2$ & $290,5-352,2$ & $295,2-352,9$ & $303,2-348,2$ \\
\hline & $95 \%$-й ІД & $307,3-315,7$ & $317,1-327,0$ & $320,2-330,4$ & $315,8-325,1$ \\
\hline \multirow{3}{*}{$\begin{array}{l}\text { N1A стадія, n=94 } \\
\text { ока }\end{array}$} & $\mathrm{M} \pm \mathrm{m}$ & $307,3 \pm 18,6$ & $320,1 \pm 15,0$ & $322,5 \pm 14,5$ & $316,4 \pm 13,9$ \\
\hline & коливання & $275,8-341,9$ & $286,1-351,9$ & $290,3-352,9$ & $289,5-348,2$ \\
\hline & 95 \%-й ІД & $302,6-313,0$ & $315,2-325,4$ & $317,3-328,1$ & $311,7-321,6$ \\
\hline \multirow{3}{*}{$\begin{array}{l}\text { N1B стадія, } \mathrm{n}=108 \\
\text { очей }\end{array}$} & $\mathrm{M} \pm \mathrm{m}$ & $309,9 \pm 28,5$ & $325,7 \pm 27,4$ & $327,1 \pm 23,9$ & $319,4 \pm 22,7$ \\
\hline & коливання & $274,7-379,7$ & $284,7-375,5$ & $287,6-379,3$ & $287,1-365,8$ \\
\hline & 95 \%-й ІД & $300,1-320,4$ & $316,4-335,1$ & $319,5-336,3$ & $311,9-328,3$ \\
\hline \multirow{3}{*}{$\begin{array}{l}\text { N2A стадія, } n=92 \\
\text { ока }\end{array}$} & $\mathrm{M} \pm \mathrm{m}$ & $319,0 \pm 29,7$ & $330,3 \pm 31,7$ & $331,1 \pm 30,5$ & $327,4 \pm 29,8$ \\
\hline & коливання & $259,8-368,9$ & $271,4-375,8$ & $281,4-366,5$ & $272,3-364,8$ \\
\hline & 95 \%-й ІД & $300,4-338,8$ & $309,8-350,4$ & $312,8-350,9$ & $308,6-346,8$ \\
\hline \multirow{3}{*}{$\begin{array}{c}\mathrm{N} 2 \mathrm{~B} \text { стадія, } \mathrm{n}=86 \\
\text { очей }\end{array}$} & $\mathrm{M} \pm \mathrm{m}$ & $318,5 \pm 30,3$ & $328,9 \pm 32,3$ & $330,4 \pm 30,9$ & $327,0 \pm 31,4$ \\
\hline & коливання & $254,4-456,6$ & $270,0-462,8$ & $279,6-437,2$ & $270,8-407,5$ \\
\hline & $95 \%$-й ІД & $300,4-338,8$ & $309,8-350,4$ & $312,8-350,9$ & $308,6-346,8$ \\
\hline \multirow{3}{*}{$\begin{array}{c}\mathrm{N} 3 \text { стадія, } \mathrm{n}=40 \\
\text { очей }\end{array}$} & $\mathrm{M} \pm \mathrm{m}$ & $305,6 \pm 34,3$ & $318,5 \pm 30,3$ & $320,5 \pm 31,9$ & $314,7 \pm 32,9$ \\
\hline & коливання & $228,9-409,4$ & $260,3-412,6$ & $274,6-407,3$ & $249,8-389,6$ \\
\hline & 95 \%-й ІД & $282,5-330,3$ & $294,7-343,1$ & $300,1-340,8$ & $291,1-338,7$ \\
\hline
\end{tabular}

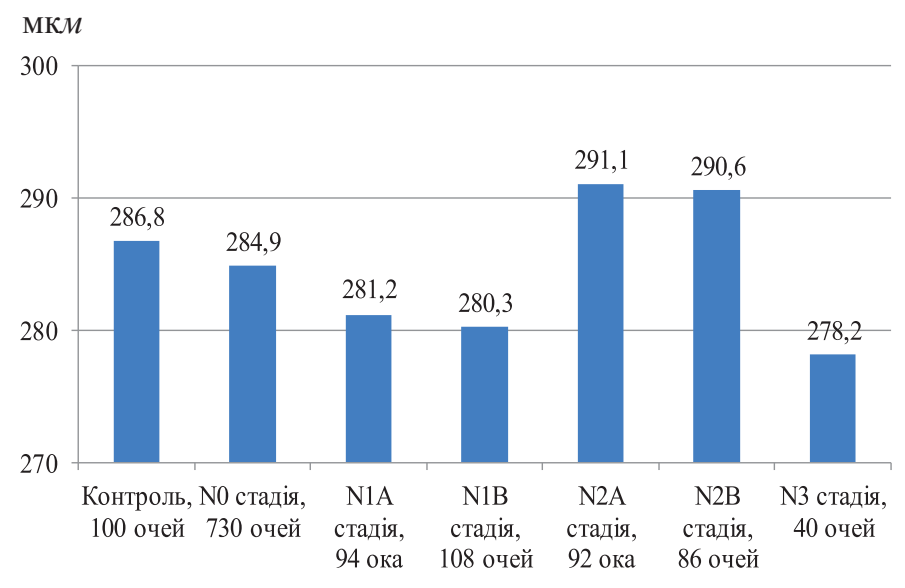

Puc. Середній показник середньої товщини перимакулярної зони сітківки у хворих на діабетичну полінейропатію залежно від тяжкості захворювання

тичній А й В ДПН та стадії тяжких ускладнень ДПН даний показник достовірно не відрізнявся від такого у групі контролю $(286,8 \pm 13,4$ мкм) (p>0,05).

Як видно з табл. 3, аналіз показників товщини перимакулярної зони темпорального, назального, верхнього та нижнього секторів сітківки у хворих на ДПН не виявив її залежності від тяжкості захворювання (табл. 3).

Дані про середню товщину макулярної зони сітківки у хворих на ЦД є суперечливими: повідомлялося як про збільшення, так і про зменшення іiі товщини за наявності та без ознак ДР, та наводилися різні патогенетичні механізми, які пояснюють ці зміни [3-5]. Pemp B. із співавторами вважають потоншання внутрішніх шарів сітківки у поєднанні зі зниженою авто- номною регуляцією у пацієнтів із ЦД 1-го типу з непроліферативною ДР ранньою ознакою ретинальної та системної нейропатії [8]. Отримані нами результати узгоджуються з думкою Srinivasan S. із співавторами, які вважають, що ОКТ є неінвазивною технологією, здатною виявити ранні структурні зміни сітківки у пацієнтів із діабетичною периферичною нейропатією, які можуть слугувати офтальмологічними маркерами ступеня іiі тяжкості [15].

\section{Висновки}

1. У результаті проведених досліджень у хворих на діабетичну полінейропатію виявлено, що середній показник фовеолярної товщини сітківки у хворих на асимптоматичну А ДПН був на $9,1 \%$, асимптоматичну В ДПН - на 8,9\%, стадію тяжких ускладнень ДПН - на $12,7 \%$ менше відповідного у здорових осіб $(263,9 \pm 25,9$ мкм $)(\mathrm{p}<0,05)$.

2. У хворих на цукровий діабет не виявили залежності товщини парамакулярної та перимакулярної зон сітківки від тяжкості діабетичної полінейропатії.

\section{Література}

1. Boulton A. J. Diabetic neuropathy: classification, measurement and treatment / A. J. Boulton // Curr Opin Endocrinol Diabetes Obes. - 2007. - Vol. 14, № 2. - P. 141-145.

2. Carpineto $P$. Neuroretinal alterations in the early stages of diabetic retinopathy in patients with type 2 diabetes mellitus / P. Carpineto, L. Toto, R. Aloia [et al.] // Eye (Lond). - 2016. - Vol. 30, № 5. - P. 673-679. 
Показники товщини різних секторів перимакулярної зони сітківки у хворих на ДПН

Табличя 3 залежно від тяжкості захворювання

\begin{tabular}{|c|c|c|c|c|c|}
\hline Групи & Показники, мкм & Темпоральна & Верхня & Назальна & Нижня \\
\hline \multirow{3}{*}{$\begin{array}{c}\text { контроль, } \\
\mathrm{n}=100 \text { очей }\end{array}$} & $\mathrm{M} \pm \mathrm{m}$ & $281,1 \pm 16,2$ & $288,3 \pm 11,0$ & $301,1 \pm 14,2$ & $276,8 \pm 12,1$ \\
\hline & коливання & $257,9-302,3$ & $263,7-309,2$ & $277,2-328,4$ & $260,3-307,7$ \\
\hline & 95\%-й ІД & $276,2-286,4$ & $284,8-292,7$ & $296,8-305,9$ & $271,8-280,4$ \\
\hline \multirow{3}{*}{$\begin{array}{l}\text { N0 стадія, } \\
\text { n=730 очей }\end{array}$} & $\mathrm{M} \pm \mathrm{m}$ & $280,1 \pm 16,9$ & $287,8 \pm 11,4$ & $298,5 \pm 14,0$ & $273,1 \pm 13,1$ \\
\hline & коливання & $256,6-303,9$ & $263,2-309,9$ & $270,9-327,9$ & $251,8-307,1$ \\
\hline & 95\%-й ІД & $275,2-285,9$ & $284,1-290,8$ & $297,1-308,4$ & $267,3-278,2$ \\
\hline \multirow{3}{*}{$\begin{array}{l}\text { N1А стадія, } \\
\text { n=94 ока }\end{array}$} & $\mathrm{M} \pm \mathrm{m}$ & $278,9 \pm 18,7$ & $285,1 \pm 18,9$ & $292,1 \pm 16,4$ & $268,7 \pm 15,9$ \\
\hline & коливання & $253,1-315,3$ & $248,9-327,1$ & $261,2-325,2$ & $227,5-307,1$ \\
\hline & 95\%-й ІД & $271,8-286,7$ & $280,2-291,2$ & $288,8-297,5$ & $261,1-273,9$ \\
\hline \multirow{3}{*}{$\begin{array}{l}\text { N1B стадія, } \\
\text { n=108 очей }\end{array}$} & $\mathrm{M} \pm \mathrm{m}$ & $276,8 \pm 19,5$ & $284,6 \pm 19,7$ & $291,7 \pm 17,8$ & $267,9 \pm 16,2$ \\
\hline & коливання & $252,2-324,7$ & $245,6-338,3$ & $259,3-335,4$ & $225,7-316,2$ \\
\hline & 95\%-й ІД & $269,5-283,9$ & $279,5-290,5$ & $286,5-298,3$ & $259,8-272,6$ \\
\hline \multirow{3}{*}{$\begin{array}{c}\text { N2A стадія, } \\
\text { n=92 ока }\end{array}$} & $\mathrm{M} \pm \mathrm{m}$ & $287,4 \pm 28,6$ & $290,1 \pm 29,8$ & $305,7 \pm 27,8$ & $281,3 \pm 30,8$ \\
\hline & коливання & $262,3-337,3$ & $257,8-379,4$ & $273,5-356,3$ & $253,2-342,1$ \\
\hline & 95\%-й ІД & $277,2-298,1$ & $279,8-300,9$ & $295,8-315,2$ & $270,1-292,2$ \\
\hline \multirow{3}{*}{$\begin{array}{l}\text { N2B стадія, } \\
\text { n=86 очей }\end{array}$} & $\mathrm{M} \pm \mathrm{m}$ & $286,8 \pm 29,5$ & $289,6 \pm 30,7$ & $305,2 \pm 29,6$ & $280,7 \pm 31,5$ \\
\hline & коливання & $259,1-363,4$ & $246,1-389,6$ & $270,3-386,1$ & $236,9-367,4$ \\
\hline & 95\%-й ІД & $275,4-297,3$ & $277,9-299,6$ & $294,7-314,5$ & $269,3-291,8$ \\
\hline \multirow{3}{*}{$\begin{array}{l}\text { N3 стадія, } \\
\text { n=40 очей }\end{array}$} & $\mathrm{M} \pm \mathrm{m}$ & $274,9 \pm 30,3$ & $280,7 \pm 30,6$ & $289,9 \pm 30,3$ & $267,2 \pm 31,6$ \\
\hline & коливання & $244,1-336,7$ & $201,5-345,3$ & $256,8-348,3$ & $161,4-301,4$ \\
\hline & 95\%-й ІД & $263,3-285,8$ & $269,3-291,4$ & $278,4-300,2$ & $256,7-287,9$ \\
\hline
\end{tabular}

3. Demir M. Central macular thickness in patients with type 2 diabetes mellitus without clinical retinopathy / M. Demir, E. Oba, B. Dirim // BMC Ophthalmol. 2013. - Vol. 13. - P. 11.

4. van Dijk H. W. Early neurodegeneration in the retina of type 2 diabetic patients / H. W. van Dijk, F. D. Verbraak, P. H. Kok [et al.] // Invest Ophthalmol Vis Sci. - 2012. - Vol. 53, № 6. - P. 2715-2719.

5. Gundogan F. C. Early Neurodegeneration of the Inner Retinal Layers in Type 1 Diabetes Mellitus / F. C. Gundogan, F. Akay, S. Uzun [et al.] // Ophthalmologica. - 2016. - Vol. 235, № 3. - P. 125-132.

6. Kim J. H. Associations between individual retinal layer thicknesses and diabetic peripheral neuropathy using retinal layer segmentation analysis / J. H. Kim, M. W. Lee, S. H. Byeon [et al.] // Retina. - 2017. № 7. - [Epub ahead of print].

7. $N g D . S$. Retinal ganglion cell neuronal damage in diabetes and diabetic retinopathy / D. S. Ng, P. P. Chiang, G. G. Tan [et al.] // Clin Exp Ophthalmol. 2016. - Vol. 44, № 4. - P. 243-250.

8. Pemp B. Correlation of retinal neurodegeneration with measures of peripheral autonomic neuropathy in type 1 diabetes / B. Pemp, S. Palkovits, K. Howorka [et al.] // Acta Ophthalmol. - 2018. - № 5. - [Epub ahead of print].

9. Rodrigues E. Diabetes induces changes in neuroretina before retinal vessels: a spectral-domain optical coherence tomography study / E. Rodrigues, M. G. Urias, F. M. Penha [et al.] // Int J Retina Vitreous. 2015. - № 15. - P. 1-4.
10. Shahidi A. M. Exploring retinal and functional markers of diabetic neuropathy / A. M. Shahidi, G. P. Sampson, N. Pritchard [et al.] // Clin Exp Optom. - 2010. - Vol. 93, № 5. - P. 309-323.

11. Shahidi A. M. Retinal nerve fiber layer thinning associated with diabetic peripheral neuropathy / A. M. Shahidi, G. Sampson, N. Pritchard // Diabetes Med. - 2012. - № 29. - e106-e111.

12. Srinivasan $S$. Focal loss volume of ganglion cell complex in diabetic neuropathy / S. Srinivasan, N. Pritchard, G. P. Sampson // Clin Exp Optom. - 2016. - Vol. 99, № 6. - P. 526-534.

13. Srinivasan $S$. Retinal tissue thickness is reduced in diabetic peripheral neuropathy / S. Srinivasan, N. Pritchard, D. Vagenas // Curr Eye Res. - 2016. Vol. 41. - P. 1359-1366.

14. Srinivasan $S$. Optical coherence tomography predicts 4-year incident diabetic neuropathy / S. Srinivasan, C. Dehghani, N. Pritchard [et al.] // Ophthalmic Physiol Opt. - 2017. - Vol. 37, № 4. - P. 451-459.

15. Srinivasan $S$. Diagnostic capability of retinal thickness measures in diabetic peripheral neuropathy / S. Srinivasan, N. Pritchard, G. P. Sampson [et al.] // J Optom. - 2017. - Vol. 10, № 4. - P. 215-225.

16. Simo $R$. Neurodegeneration in the diabetic eye: new insights and therapeutic perspectives / R. Simo, C. Hernandez; European Consortium for the Early Treatment of Diabetic Retinopathy (EUROCONDOR) // Trends Endocrinol Metab. - 2014. - Vol. 25, № 1. - P. 23-33. 


\title{
ОСОБЕННОСТИ МОРФОЛОГИЧЕСКИХ ИЗМЕНЕНИЙ СЕТЧАТКИ У БОЛЬНЫХ ДИАБЕТИЧЕСКОЙ ПОЛИНЕЙРОПАТИЕЙ В ЗАВИСИМОСТИ ОТ ТЯЖЕСТИ ЗАБОЛЕВАНИЯ
}

\section{М. А. Карлийчук}

В работе описаны изменения толщины сетчатки в фовеоле, верхней и нижней половинах сетчатки, а также в темпоральном, верхнем, назальном и нижнем квадрантах пара- и перимакулярной зон у больных диабетической полинейропатией в зависимости от тяжести заболевания и в сравнении с показателями здоровых лиц.

Ключевые слова: сахарный диабет, диабетическая полинейропатия, морфологические изменения сетчатки, оптическая когерентная томография.

\section{FEATURES OF THE RETINAL MORPHOLOGY CHANGES IN PATIENTS WITH DIABETIC POLYNEUROPATHY DEPENDING ON THE SEVERITY OF THE DISEASE}

\author{
M. A. Karliychuk \\ Bukovinian State Medical University of the Ministry of Public Health of Ukraine \\ Chernivtsi, Ukraine
}

It is known that diabetic polyneuropathy (DPN) is a risk factor for compromised retinal structural integrity in patients with diabetes, independent of diabetic retinopathy. Given that optical coherent tomography (OCT) can detect diabetes-related compromise in multiple layers of the retina, it is logic to suppose the diagnostic potential of the OCT-derived retinal parameters in differentiating individuals with DPN and evaluation of its severity.

The objective was to study the retinal morphology changes in the patients with diabetic polyneuropathy depending on the severity of the disease by means of an OCT.

Materials and methods of research. 575 patients (1150 eyes) with type II DM and 50 non-diabetic healthy persons (100 eyes) aged 55,9 7,8 years were examined. The features of retinal morphology changes in patients with DPN depending on the severity of the disease were studied by means of OCT of the retina. An average retinal thickness in the fovea, para- and perimacular zones with diameter of examination in $1 \mathrm{~mm}, 3 \mathrm{~mm}, 5 \mathrm{~mm}$, respectively were analyzed. The thickness of the retina in the superior and inferior halves, in the temporal, nasal and inferior quadrant of the para- and perimacular zone was determined. In accordance with the classification of DPN, taking into account the severity in 63,5\% (365 patients) with DM, the diagnosis of DPN was excluded (stage N0). DPN was diagnosed in 36,5\% (210 patients) with DM.

Results. Analyzing the index of the foveal thickness in the patients with the DPN its dependence on the severity of the disease was revealed. The mean foveal thickness in the patients with asymptomatic DPN A, asymptomatic DPN B, and disabling DPN was $9,1 \%, 8,9 \%$, and $12,7 \%$ less than that in age-matched healthy individuals $(263,9 \pm 25,9 \mu \mathrm{m})(\mathrm{p}<0,05)$. In the patients with symptomatic DPN A and B that index had no statistical difference as compared with controls ( $\mathrm{p}>0,05)$. The lowest mean foveal thickness was found in the patients with disabling DPN. In symptomatic DPN A, B, and in diabetic patients without DPN this index was $17,0 \%, 14,1 \%(p<0,001)$, and $11,0 \%(p<0,05)$ higher than that in disabling DPN. The analysis of the retinal thickness in the superior and inferior halves, in the temporal, nasal and inferior quadrant of the para- and perimacular zones in the patients with DPN did not reveal the dependence on the severity of the disease.

Conclusions. As a result of the studies it was found that a mean foveal thickness in the patients with diabetic polyneuropathy was $9,1 \%, 8,9 \%, 12,7 \%$ less in patients with asymptomatic A DPN, asymptomatic DPN B, and disabling DPN respectively than that in healthy individuals $(p<0,05)$. A dependence of para- and perimacular retinal thickness on the severity of the diabetic polyneuropathy in the patients with diabetes mellitus was not found.

Key words: diabetes mellitus, diabetic polyneuropathy, retinal morphology changes, optical coherent tomography.

Стаття надійшла до редакції 19.07.2018 р. 